Original Paper http://ajol.info/index.php/ijbcs http://indexmedicus.afro.who.int

\title{
Antioxidant and antiproliferative activities on prostate and cervical cultured cancer cells of five medicinal plant extracts from Burkina Faso
}

\author{
Bagora BAYALA ${ }^{1,2,3,4^{*}}$, Théodora Mahoukèdè ZOHONCON ${ }^{1,2,5,6}$, \\ Florencia Wendkuuni DJIGMA ${ }^{1,2}$, Christelle NADEMBEGA ${ }^{1,2}$, Silvère BARON ${ }^{3}$, \\ Jean-Marc LOBACCARO ${ }^{3}$ and Jacques SIMPORE LI, $^{1,5,6}$
${ }^{1}$ Laboratoire de Biologie Moléculaire et de Génétique (LABIOGENE), Université Joseph KI-ZERBO, 03 BP 7021, Ouagadougou 03, Burkina Faso.
${ }^{3}$ Laboratoire Génétique, Reproduction \& Développement, UMR CNRS 6293, INSERM U1103, Université Clermont Auvergne, 28, Place Henri Dunant, BP 38, F63001, Clermont-Ferrand, France.
${ }^{4}$ Université Norbert ZONGO, BP 376 Koudougou, Burkina Faso.
${ }^{5}$ Université Saint Thomas d'Aquin (USTA), 06 BP 10212 Ouagadougou 06, Burkina Faso. ${ }^{6}$ Hôpital Saint Camille de Ouagadougou (HOSCO), 09 BP 444 Ouagadougou 09, Burkina Faso. \\ ${ }^{2}$ Centre de Recherche Biomoléculaire Pietro Annigoni (CERBA), 01 BP 216 Ouagadougou 01, Burkina Faso. \\ *Corresponding authors; E-mail: b.bayala@labiogene.org ; bayalabagora@gmail.com;
}

$$
\text { Tel.: +22676696166 }
$$

\begin{abstract}
Medicinal plants are a potential source of drug discovery and development of cancer chemoprevention drugs. Thus, the aim of this work was to study the antioxidant and antiproliferative activities of hydromethanolic extracts of Musa sapientum L., Cassia italica (Mill.) Spreng., Crateva adansonii DC., Euphorbia hirta L. and Ceratotheca sesamoides Endl. from Burkina Faso. The antioxidative activity of hydromethanolic extracts of plant was assessed using DPPH radical scavenging assay and ABTS+ radical cation decolorisation assay. Antiproliferative activity was evaluated by MTT assay. Of these five plant extracts, hydromethanolic extract of Euphorbia hirta leaf twigs showed the best antioxidant activity both by DPPH $\left(\mathrm{IC}_{50}=0.53 \pm 0.04 \mu \mathrm{g}\right.$ extract / $\mu \mathrm{g}$ DPPH $)$ and ABTS $(\mathrm{C}=0.302 \pm 0.003 \mu \mathrm{MET} / \mathrm{g}$ extract $)$ methods. In addition, hydromethanolic extract of Euphorbia hirta leaf twigs showed the best antiproliferative activity on LNCaP cell lines of prostate cancer while the hydromethanolic extract of the Ceratotheca sesamoides leaf stems showed the best antiproliferative activity on the HeLa cell lines of cervical cancer. This work has shown not only the antioxidant and anticancer activities of these five local plants, but also the potential valorization of these species used in traditional medicine in Burkina Faso.
\end{abstract}

(C) 2020 International Formulae Group. All rights reserved.

Keywords: Cancer, antioxydant, antiproliferative, Medicinal plants, Burkina Faso.

\section{INTRODUCTION}

Traditional plants generally have many therapeutic properties (Sarr et al., 2015). Indeed, medicinal plants are a potential source of drug discovery and development of cancer chemoprevention drugs. Most African people still rely heavily on traditional medicine (Zank and Hanazaki, 2017). In fact, more than $80 \%$ of 
African population uses medicinal plants (Shewamene et al., 2020). Plants are reservoirs for novel chemical molecules and provide a promising line for research on cancer (Iqbal et al., 2017). Indeed, several extracts of African medicinal plants are known to have properties against cancer cells (Ambe et al., 2016; Bayala et al., 2019; Moore et al., 2016). Musa sapientum, Cassia italica, Crateva adansonii, Euphorbia hirta and Ceratotheca sesamoides are used in traditional medicine in Burkina Faso to treat inflammatory and oxidative diseases (Nacoulma, 1996). These plants are known in the literature for their many biological properties. Regarding Musa sapientum, ethanol extracts have antiplasmodium and anti-toxoplasma activities in vitro (Leesombun et al., 2019) and an antidepressant activity possibly mediated by $\alpha 1$-adrenergic and dopaminergic D2 receptors and without anxiolytic effect (Salako et al., 2019). Stem extract of Musa sapientum showed anticonvulsant and antioxidant effects on both acute and chronic epilepsy experimental models (Reddy et al., 2018). Proteins extracted from flowers showed antibacterial effects against gram-positive and negative bacteria (Sitthiya et al., 2018). A significant antidepressant-like activity was found in Musa sapientum stem extract in experimental models in mice (Reddy et al., 2016). Methanol extract of stems has significant antihypercholesterolemic and antioxidant effects (Dikshit et al., 2016). At last, Musa sapientum decoction extract of fresh unripe peels exhibited strong antioxidant activity (Phuaklee et al., 2012).

Ethanolic extract of the whole parts of Cassia italica showed a dose-dependent inhibition of prostaglandin release effect using rat peritoneal leucocytes (Jain et al., 1997). Phytol, 1-hexyl-2-nitrohexane and 2isopropyl-5-methylcyclohexyl 3- (1- (4chlorophenyl) -3-oxobutyl) -coumarin-4-yl carbonate are three compounds identified in the extract $C$. adansonii that showed anti- inflammatory properties (Thirumalaisamy et al., 2018). Ahama-Esseh et al. ( 2017) pointed out that various $C$. adansonii leaf samples have anti-inflammatory activities. While dichloromethane / methanol extracts of stem bark exhibit anti-cancer activity on breast cancer cells MCF-7 and MDA-MB-231 (Zingue et al., 2016). The stem bark also possesses analgesic activity against peripheral and central mediated pain sensation and also antioxidant properties (Udeh \& Onoja, 2015).

Euphorbia hirta has anthelmintic properties (Nsereko et al., 2019), as well antiinflammatory and anxiolytic effects on neonatal asthmatic rats with inflammation (Xia et al., 2018). Isolated compounds caffeic acid and epicatechin 3-gallate showed antibacterial effect against Pseudomonas aeruginosa (Perumal et al., 2017). Aerial parts have in vitro antimicrobial activities against the bacterium Aeromonas hydrophila (Sheikhlar et al., 2017). Decoctions of leaves and bark are used for the treatment of dengue (de Guzman et al., 2016). E. hirta also inhibits the survival of MCF-7 cells with a half inhibitory concentration (IC50) value of $25.26 \mu \mathrm{g} / \mathrm{mL}$ at $24 \mathrm{~h}$ (Kwan et al., 2016). Chen et al. (2015) described the in vitro anti-inflammatory activity of fractionated E. hirta aqueous extract on rabbit synovial fibroblasts.

Toyin et al. (2012) showed antidiarrheal activity of aqueous leaf extract of Ceratotheca sesamoides in rats, while extract from leaves have antiviral activities (Obi et al., 2006).

According to these data, several other studies have been carried out on these five plants, but, to date, no study has yet been carried out on the anticancer activity of these five plants on prostate and cervical cancers cells. Based on that, we evaluated the antioxidant and antiproliferative activities of hydromethanolic extracts of Musa sapientum, Cassia italica, Crateva adansonii, Euphorbia hirta and Ceratotheca sesamoides from Burkina Faso on cells derived from prostate (LNCaP) and cervical (HeLa) cancers. 


\section{MATERIALS AND METHODS Vegetal material and Extraction}

The plant material of Musa sapientum, Cassia italica, Crateva adansonii, Euphorbia hirta, and Ceratotheca sesamoides were collected in August 2017 in Burkina Faso with respective GPS coordinates (Table 1). Taxonomic identities were confirmed by Dr. Abdoulaye SEREME, Plant Biology Researcher, Botanist of "Centre National de la Recherche Scientifique et Technologique (CNRST)". The different samples of harvested plants were dried in the laboratory away from sunlight and then reduced to powder. Each crude extract was obtained by hydromethanolic maceration (80:20) for 48 hours with frequent agitation. The mixture was filtered with Whatman No. 1 filter paper and the filtrate was concentrated by rotary evaporator with vacuum at $40{ }^{\circ} \mathrm{C}$, poured in glass Petri dishes and brought to dryness at $40{ }^{\circ} \mathrm{C}$ oven.

\section{Antioxidant activity}

\section{DPPH (2,2-diphenyl-1-picryl-hydrazyl- hydrate) radical scavenging assay \\ DPPH (Sigma-Aldrich, L'Ile d'Abeau,} France) radical scavenging activity was measured as described by Velasquez (Velázquez et al., 2003) with modifications. Briefly, plant extract at $0.625 \mathrm{mg} / \mathrm{mL}$ was diluted at different concentrations in a 96-well plate. Then, $100 \mu \mathrm{L}$ of each extract concentration was mixed with $100 \mu \mathrm{L}$ of DPPH (30 mg / L in methanol). After $30 \mathrm{~min}$ of incubation in the dark, the absorbance was read at $517 \mathrm{~nm}$ using a UV / Visible spectrophotometer for Radical scavenging capacity. Gallic acid was used as a control. The radical scavenging activity was expressed as a percentage inhibition according to the formula:

RSC $(\%)=\frac{\text { Absorbance Blank }- \text { Absorbance Sample }}{\text { Absorbance Blank }} X 100$

RSC: Radical scavenging capacity.
Concentrations were expressed in $\mu \mathrm{g}$ of extracts / $\mu \mathrm{g}$ of DPPH by formula:

Concentration $=\frac{\text { Mass of extract }}{\text { Mass of DPPH }}$

That is to say:

$\mathrm{C}=\frac{\text { Concentration of extract } \mathrm{x} \text { Volume of extract }}{\text { Concentration of DPPH } \mathrm{x} \text { Volume of DPPH }}$

C: Concentration.

The concentration necessary for scavenging $50 \%$ of the DPPH radicals was then determined graphically according to the formula: IC50 = $\mathrm{f}(\log \mathrm{C})$ with being the concentration of extract and the equation of the regression line $\mathrm{y}=\mathrm{ax}+\mathrm{b}$ is used to determine $\mathrm{IC}_{50}$.

\section{ABTS $^{+}$radical cation decolorization assay}

The spectrophotometric analysis of $\mathrm{ABTS}^{+}\left(2,2^{\prime}\right.$-azino-bis(3-ethylbenzothiazoline6-sulfonic acid)) scavenging activity was determined according Re et al. (1999). Briefly, preparation of $\mathrm{ABTS}^{+}$solution was done by dissolving $10 \mathrm{mg}$ of ABTS in $2.6 \mathrm{~mL}$ of distilled water. Then, $1.7212 \mathrm{mg}$ of potassium persulfate was added and the mixture kept in the dark at room temperature for 12 hours. The mixture was then diluted with ethanol in order to obtain an absorbance of $0.70 \pm 0.02$ to 734 nm. In 96-well plates, $50 \mu \mathrm{L}$ of ethanolic extract solution at an initial concentration of $0.625 \mathrm{mg} / \mathrm{mL}$ (Musa sapientum, Cassia italica, Crateva adansonii and Ceratotheca sesamoides) and of $0.125 \mathrm{mg} / \mathrm{mL}$ (Euphorbia hirta) were added to $200 \mu \mathrm{L}$ of freshly prepared $\mathrm{ABTS}^{+}$solution. The same process was carried out for gallic acid at an initial concentration of $0.0125 \mathrm{mg} / \mathrm{mL}$ used as standard. The mixture made in the 96-well plates was then incubated in the dark at room temperature $\left(25^{\circ} \mathrm{C}\right)$ for 15 min and the absorbance was read at $734 \mathrm{~nm}$ against a standard curve of 5,7,8-tetramethyl2-carboxylic acid 6-hydroxy-2 (Trolox, SigmaAldrich) using a spectrophotometer. The plant extract activity on the radical cation $\mathrm{ABTS}^{+}$. 
was expressed in micromoles Trolox equivalent per gram of extract ( $\mu \mathrm{mol} \mathrm{TE} / \mathrm{g}$ ) using the following formula: $\mathrm{C}=(\mathrm{cx} \mathrm{D}) / \mathrm{Ci}, \mathrm{C}$ being the concentration of plant extract in $\mu \mathrm{mol}$ TE / g; c, the concentration of the sample read; $\mathrm{D}$, the dilution factor and $\mathrm{Ci}$, concentration of the stock solution.

\section{Cancer cell lines and culture conditions}

LNCaP (Lymph Node Cancer of the Prostate) cells are an androgen responsive prostate cancer cell line with a low metastatic potential derived from a lymph node metastasis (Horoszewicz et al., 1983). HeLa (Henrietta Lacks) cells derived from tumor of the cervix (C, 1974). All these cells are available through the GReD (Génétique, Reproduction \& Développement) Laboratory (University Clermont-Auvergne, France) and others manipulations were carried out in GReD and CERBA/LABIOGEME Laboratories. They are cultured and maintained at $37{ }^{\circ} \mathrm{C}$ in a chamber moistened with $5 \% \mathrm{CO}_{2}$ in $75 \mathrm{~cm}^{2}$ flasks of tissue culture, in medium supplemented with $10 \%$ fetal calf serum (FCS, Biowest, Nuaillé, France), $1 \%$ penicillin and $1 \%$ streptomycin
(Invitrogen, Oslo, Norway). Cells were maintained in RPMI-1640 (Roswell Park Memorial Institute) medium (Invitrogen).

\section{Antiproliferative activity}

3[4,5-dimethylthiazol-2-yl]-

diphenyltetrazolium bromide (Sigma-Aldrich) assay (MTT) was used to measure the cell survival. Briefly, 50,000 cells/mL were seeded for $24 \mathrm{~h}$ in 96-well plates. After $24 \mathrm{~h}$, extracts were added. And after $72 \mathrm{~h}$ incubation, the number of living cells was measured as described (Bayala et al., 2014, 2018) using a microplate reader type Bio-Rad 11885 at 490 nm. Experiments were performed in sextuplicate with three independent experiments on each cell line.

\section{Statistical analysis}

All data are presented as mean \pm standard deviation. The data were analyzed by analysis of variance followed by the Turkey multiple comparison test. The analyses were performed using XLSTAT 7.1 software. $\mathrm{P}<$ 0.05 was used as a criterion for statistical significance.

Table 1: GPS geographic location of plants.

\begin{tabular}{lcc}
\hline Plant & \multicolumn{2}{c}{ GPS coordinates } \\
\cline { 2 - 3 } Musa sapientum & X & Y \\
Cassia italica & 662753 & 1369094 \\
Crateva adansonii & 678088 & 1374329 \\
Euphorbia hirta & 679992 & 1373734 \\
Ceratotheca sesamoides & 662723 & 1369080 \\
\hline
\end{tabular}




\section{RESULTS}

The antioxidant activities of the hydromethanolic extracts of Musa sapientum, Cassia italica, Crateva adansonii, Euphorbia hirta and Ceratotheca sesamoides are presented in Table 1. From these results, it appears that the extracts of the leafy twigs of Euphorbia hirta presented the highest inhibition of DPPH with IC50 of $0.53 \pm 0.04$ $\mu \mathrm{g}$ extract / $\mu \mathrm{g}$ DPPH $(\mathrm{p}<0.05)$ and Crateva adansonii bark the lowest inhibition (IC50 of $15.73 \pm 2.04 \mu \mathrm{g}$ extract / $\mu \mathrm{g}$ DPPH) (Table 1). In ABTS radical cations inhibition, leafy twigs extract of Euphorbia hirta also showed the highest activity $(0.302 \pm 0.003 \mu \mathrm{MET} / \mathrm{g}$ of extract) $(\mathrm{p}<0.05)$ while those of Crateva adansonii bark hydromethanolic extracts has the lowest activity $(0.024 \pm 0.002 \mu \mathrm{MET} / \mathrm{g}$ of extract) (Table 2). The gallic acid used as a standard exhibited a good activity with an IC50 of inhibition of the DPPH radicals of $0.11 \pm$ $0.04 \mu \mathrm{g}$ extract $/ \mu \mathrm{g}$ DPPH and an inhibition concentration of the ABTS cation radicals of $2.665 \pm 0.314 . \mu \mathrm{MET} / \mathrm{g}$ extract (Table 2).

The results of the tests of the antiproliferative activity are recorded in Table 2. This table presents the different $\mathrm{IC}_{50}$ of $M u s a$ sapientum, Cassia italica, Crateva adansonii, Euphorbia hirta and Ceratotheca sesamoides hydrometanolic extracts. Extract of the leafy twigs of Euphorbia hirta has antiproliferative activity on $\mathrm{LNCaP}$ cell lines of prostate cancer are $251.15 \pm 6.5 \mu \mathrm{g} / \mathrm{mL}$. In HeLa cell lines of cervical cancer, leaf stems of Ceratotheca sesamoides had an activity of $723.25 \pm 3.82 \mu \mathrm{g}$ / $\mathrm{mL}$. Figure 1 shows the viability of $\mathrm{LNCaP}$ cells according to the concentrations of each extract used. As for Figure 2, it also demonstrates the viability of HeLa cells of cervical cancer according to the concentrations of each extract. Cisplatin was used as standard on LNCaP cells of prostate cancer and HeLa cells of cervical cancer (Figures 1 and 2).

Table 2: Antioxydant activity of hydromethanolic extracts of Musa sapientum, Cassia italica, Crateva adansonii, Euphorbia hirta and Ceratotheca sesamoides.

Antioxydant activity

\begin{tabular}{|c|c|c|}
\hline Sample & $\begin{array}{c}\text { DPPH, } \\
\mathrm{IC}_{50}(\mu \mathrm{g} \text { extract } / \mu \mathrm{g} \text { DPPH })\end{array}$ & $\begin{array}{c}\text { ABTS, } \\
\text { C }(\mu \mathrm{MET} / \mathrm{g} \text { extrai }\end{array}$ \\
\hline Musa sapientum (F.). & $5.7 \pm 0.91^{\mathrm{d}}$ & $0.032 \pm 0.005^{\mathrm{d}}$ \\
\hline Cassia italica (Rx F.) & $5.13 \pm 1.06^{\mathrm{d}}$ & $0.029 \pm 0.004^{\mathrm{a}}$ \\
\hline Crateva adansonii (F.) & $3.65 \pm 0.88^{c}$ & $0.041 \pm 0.004^{\mathrm{c}}$ \\
\hline Euphorbia hirta (Rx F.) & $0.53 \pm 0.04^{b}$ & $0.302 \pm 0.003^{\mathrm{b}}$ \\
\hline Ceratotheca sesamoides (Tg F.) & $2.02 \pm 0.94^{\mathrm{c}}$ & $0.027 \pm 0.004^{\mathrm{d}}$ \\
\hline Crateva adansonii (E.) & $15.73 \pm 2.04^{\mathrm{e}}$ & $0.024 \pm 0.002^{\mathrm{d}}$ \\
\hline Gallique acid & $0.11 \pm 0.04^{\mathrm{a}}$ & $2.665 \pm 0.314^{\mathrm{a}}$ \\
\hline
\end{tabular}

$\mathrm{IC}_{50}$, Inhybitory concentration 50; C, Concentration; DPPH, (2,2-diphenyl-1-picrylhydrazyl); ABTS (2,20-azinobis-[3ethylbenzothiazoline-6-sulfonic acid]); Values are expressed as mean values \pm SD. $n=3$ independent experiments in triplicate for the measurement of antioxidant activity; DPPH activities is expressed as $\mathrm{IC}_{50}(\mu \mathrm{g}$ Extract $/ \mu \mathrm{g} \mathrm{DPPH})$ and $\mathrm{ABTS}$ activities are given in $\mu$ mol Throlox equivalent/g of Extract. a, b, c, d, e, from the largest to the smallest activity, the same letters are used for statistically identical activities and different letters when they are statistically different in each column $(\mathrm{p}<0.05)$. F, Leaf; Rx F, leafy twigs; Tg F, Leaf Stem; E, Bark. Galic acid was used as standard. 
Table 3: $\mathrm{IC}_{50}$ of hydromethanolic extracts tested on $\mathrm{LNCaP}$ human prostate cancer cell lines and HeLa human cervical cancer cell lines.

\begin{tabular}{lcc}
\hline \multirow{2}{*}{ Sample } & \multicolumn{2}{c}{ IC $_{50}(\mu \mathrm{g} / \mathrm{mL})$} \\
\cline { 2 - 3 } Musa sapientum (F.) & LNCaP cell lines & HeLa cell lines \\
Cassia italica (Rx F.) & $>1000$ & $>1000$ \\
Crateva adansonii (F.) & $>1000$ & $>1000$ \\
Euphorbia hirta (Rx F.) & $>1000$ & $>1000$ \\
Ceratotheca sesamoides (Tg F.) & $251.15 \pm 6.50^{* * *}$ & $>1000$ \\
Crateva adansonii (E.) & $599.85 \pm 4.76^{*}$ & $723.25 \pm 3.82^{\$}$ \\
Cisplatin & $585.35 \pm 3.19^{* *}$ & $>1000$ \\
\hline
\end{tabular}

$\mathrm{IC}_{50}$, Inhybitory concentration 50; Values are expressed as mean values \pm standard deviation. $\mathrm{n}=3$ independent experiments in sextuplicate; $*, * *, * * *$ and $\$ \$ \$(\mathrm{p}<0.05)$ from lowest to highest activity and significantly different compared respectively. F, Leaf; Rx F, leafy twigs; Tg F, Leaf Stem; E, Bark. Cisplatin was used as standard.

\section{On LNCaP cell lines}
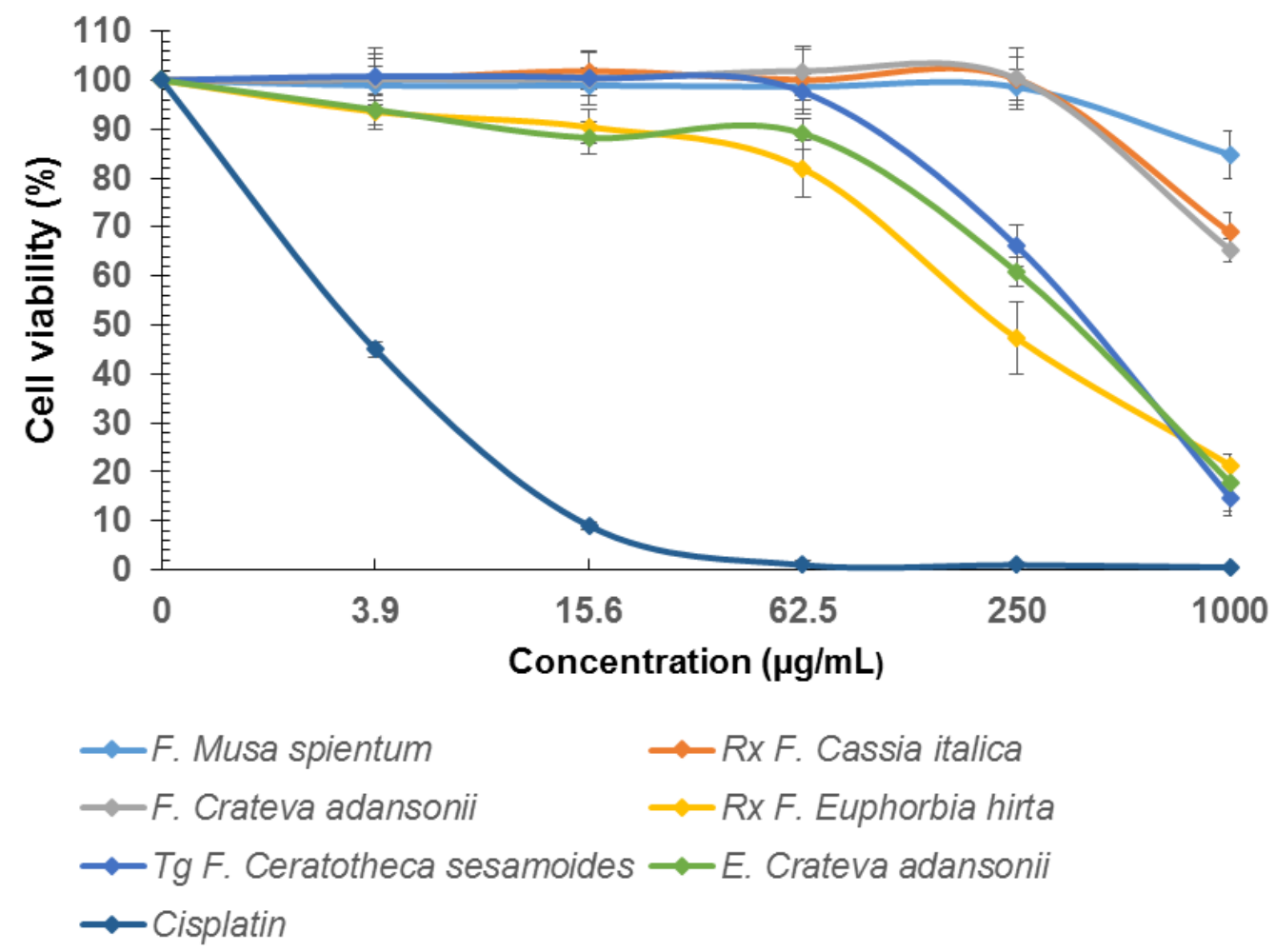

Figure 1: Dose-dependent anti-proliferative activity of hydromethanolic extracts of plant on human LNCaP cell lines of Prostate cancer.

Cell lines were treated for $72 \mathrm{~h}$. Experiments were performed 3 times in sextuplicates. F, Leaf; Rx F, leafy twigs; Tg F, Leaf Stem; E, Bark. Cisplatin was used as standard. 


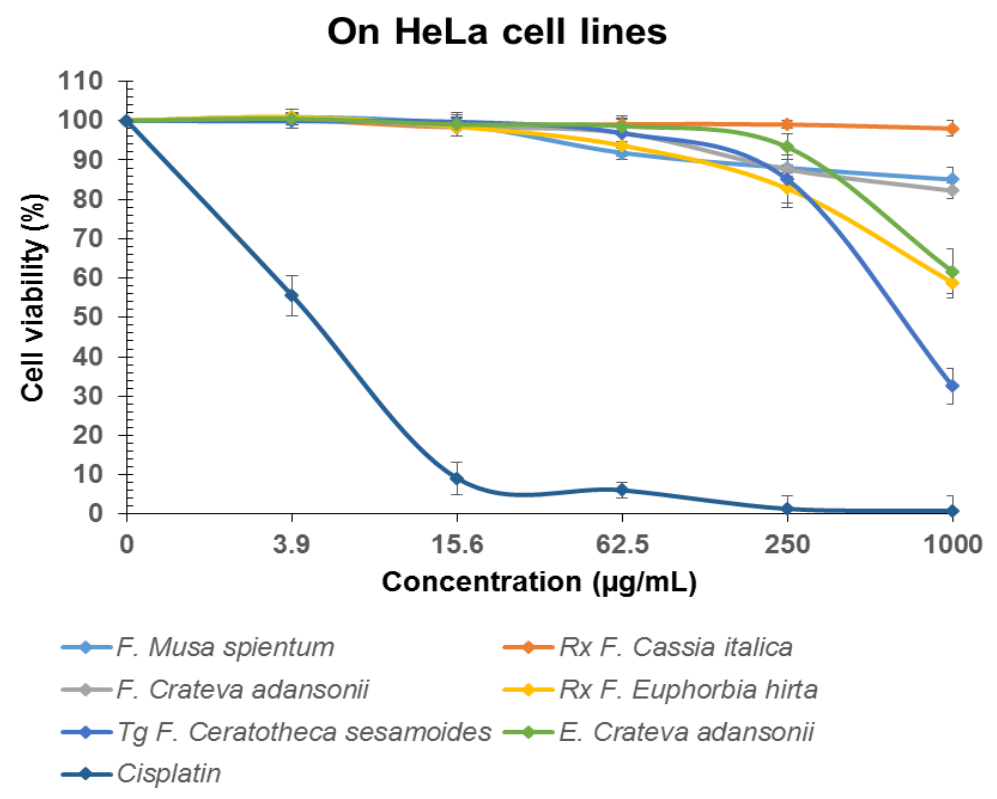

Figure 2: Dose-dependent anti-proliferative activity of hydromethanolic extracts on human HeLa cells lines of cervical cancer.

Cell lines were treated for $72 \mathrm{~h}$. Experiments were performed 3 times in sextuplicates. F, Leaf; Rx F, leafy twigs; Tg F, Leaf Stem; E, Bark. Cisplatin was used as standard.

\section{DISCUSSION}

Oxygen reactive species (ORS) are involved in physiological processes at low levels. However, excess production of ORS can become toxic to major cell components, lipids, proteins and nucleic acids (Ouattara et al., 2020) causing oxidation in the body. The DPPH and ABTS method are used to determine the antioxidant activity in vitro. The difference between DPPH anti-radical and anti-radical ABTS activities at the origin of the antioxidant activity is mainly at the level of their mechanism of action brought into play. Indeed, the DPPH involves free radicals while the ABTS involves radical cations. So, the hydromethanolic extracts of Musa sapientum, Cassia italica, Crateva adansonii, Euphorbia hirta and Ceratotheca sesamoides all exhibited antioxidant activities depending on the inhibition of radicals DPPH and cation radicals ABTS. Hydromethanolic extracts of the leafy twigs of Euphorbia hirta presented the higher inhibition of DPPH as well of ABTS radical cations. This antioxidant activity could be justified by a high content of antioxidant compounds contained in Euphorbia hirta (Basma et al., 2011). Indeed, extract of the aerial parts of Euphorbia hirta contains many acidic compounds (Yang et al., 2020) that could justify this antioxidant activity. High total phenolic and flavonoid contents, suggested that E. hirta methanolic extract is a potential antioxidant agent for the development of local natural products for disease treatment (Ismail et al., 2019). Moreover, concerning Crateva adansonii, it should also be noted that hydromethanolic extract of its leaves are more active than those of its bark. Thus, for the same plant, the activity may vary according to the parts used. The standard gallic acid exhibits stronger antioxidant activity compared to the natural hydromethanolic extracts from plants (Table 2). Indeed, gallic acid is a pure compound compared to extracts which are composed of a complex mixture of several 
compounds which could have antagonistic effects.

Hydromethanolic extracts from Musa sapientum leaves, Cassia italica twigs and leaves, Crateva adansonii leaves do not present strong inhibitory effects on both $\mathrm{LNCaP}$ and HeLa cell lines with $\mathrm{IC}_{50}>1000 \mu \mathrm{g} / \mathrm{mL}$ (Figures $1 \& 2$ ). These three extracts would therefore be active in high concentrations. Furthermore, these extracts are a mixture of several compounds whose antagonistic actions between them could also explain their low overall activity. Conversely, hydromethanolic extracts from the leafy twigs of Euphorbia hirta has a significant antiproliferative activity on the LNCaP cell lines from prostate cancer with IC50 of $251.15 \pm 6.5 \mu \mathrm{g} / \mathrm{mL}(\mathrm{P}<0.05)$ (Table 3). This activity is also higher than that of leaf stems of Ceratotheca sesamoides on HeLa cell lines of cervical cancer whose IC50 is $723.25 \pm 3.82 \mu \mathrm{g} / \mathrm{mL}(\mathrm{P}<0.05)$ (Table 3). The presence of phenolic compounds in Euphorbia hirta could explain this activity (Basma et al., 2011). Moreover, the phytochemical screening and chromatography revealed the presence of saponin, sterol, terpene, alkaloids, polyphenols, tannins and flavonoids on Euphorbia hirta extract (Yvette Fofie et al., 2015). Indeed, terpene (Gill et al., 2016), polyphenols (Costea et al., 2019; Miyata et al., 2019) and sterol (Blanco-Vaca et al., 2019) are known to have anticancer activities. Previous studies have shown that Euphorbia hirta exhibited significant inhibition of the survival of breast cancer MCF-7 cells with an $\mathrm{IC}_{50}$ of $25 \mu \mathrm{g} / \mathrm{mL}$ at $24 \mathrm{~h}$ (Kwan et al., 2016). This antiproliferative activity exerted by the hydromethanolic extract of Euphorbia hirta is concentration dependent but remains low compared to cisplatin used as standard. Comparable effects could be observed with Ceratotheca sesamoides leaf Stem and Crateva adansonii bark hydromethanolic extract. Leaf stems of Ceratotheca sesamoides as cisplatin are also concentration dependent on HeLa cells of cervical cancer.

\section{Conclusion}

This work evaluated for the first time the antioxidant and antiproliferative activities of the hydromethanolic extracts of plants from Burkina Faso on cultured cancer cells. Even though the active compounds are yet to be identified and need to be investigated further, this work constitutes a scientific basis and also allow the valorization of these local medicinal plants of Burkina Faso.

\section{COMPETING INTERESTS}

The authors declare that they have no competing interests.

\section{AUTHORS' CONTRIBUTIONS}

$\mathrm{BB}$, JS and JML designed the research; $\mathrm{BB}$ and $\mathrm{TMZ}$ performed the experiments and analyzed the data. BB, TMZ, FWD, CN, SB, JML and JS wrote the manuscript. All authors read and approved the final manuscript.

\section{ACKNOWLEDGEMENTS}

Part of this study was supported by Conférence Episcopale Italienne (CEI) and Ambassade de France au Burkina Faso (Grant stage SSHN $\mathrm{n}^{\circ}$ 948600C) for $\mathrm{BB}$ and JS; Région Auvergne, Fond Européen de Développement Régional (FEDER), Plan National de Recherche sur les Perturbateurs Endocriniens (13-MRES-PNRPE-1-CVS043), and Plan-Cancer 2016 (JMAL) for JMAL. The funders had no role in study design, data collection and analysis, decision to publish, or preparation of the manuscript.

\section{REFERENCES}

Ahama-Esseh K, Bodet C, Quashie-MensahAttoh A, Garcia M, Théry-Koné I, Dorat J, De Souza C, Enguehard-Gueiffier C, Boudesocque-Delaye L. 2017. Antiinflammatory activity of Crateva adansonii DC on keratinocytes infected by Staphylococcus aureus: From traditional practice to scientific approach using HPTLC-densitometry. $J$. 
Ethnopharm., 204: 26-35. DOI: https://doi.org/10.1016/j.jep.2017.04.001

Ambe ASA, Camara D, Ouattara D, Yapo CY, Soumahoro A, Zirihi GN, N'Guessan KE. 2016. Etude ethnobotanique, évaluation in vitro de l'activité antifongique et cytotoxique des extraits de Enantia polycarpa (DC) Engl. et Diels (Annonaceae). Int. J. Biol. Chem. Sci., 10(1): 23-34. DOI: https://doi.org/10.4314/ijbcs.v10i1.3

Basma AA, Zakaria Z, Latha LY, Sasidharan S. 2011. Antioxidant activity and phytochemical screening of the methanol extracts of Euphorbia hirta L. Asian Pac. J. Trop. Med., 4(5): 386-390. DOI: https://doi.org/10.1016/S19957645(11)60109-0

Bayala B, Bassole IHN, Gnoula C, Nebie R, Yonli A, Morel L, Figueredo G, Nikiema JB, Lobaccaro JMA, Simpore J. 2014. Chemical composition, antioxidant, antiinflammatory and anti-proliferative activities of essential oils of plants from Burkina Faso. PloS One, 9(3): e92122. DOI:

https://doi.org/10.1371/journal.pone.009 2122

Bayala B, Bassole IHN, Maqdasy S, Baron S, Simpore J, Lobaccaro JMA. 2018. Cymbopogon citratus and Cymbopogon giganteus essential oils have cytotoxic effects on tumor cell cultures. Identification of citral as a new putative anti-proliferative molecule. Biochimie, 153: $\quad 162-170 . \quad$ DOI: https://doi.org/10.1016/j.biochi.2018.02. 013

Bayala B, Sow B, Millogo V, Ouattara Y, Tamboura HH. 2019. Toxicity, cytotoxicity and biological activities of seeds of Carapa procera (DC), a native oil tree. Int. J. Biol. Chem. Sci., 13(1): 4962.

DOI: https://doi.org/10.4314/ijbcs.v13i1.5
Blanco-Vaca F, Cedó L, Julve J. 2019. Phytosterols in Cancer: From Molecular Mechanisms to Preventive and Therapeutic Potentials. Curr. Med. Chem., 26(37): 6735-6749. DOI: https://doi.org/10.2174/09298673256661 80607093111

C BJ. 1974. HeLa (for Henrietta Lacks). Science (New York, N.Y.), 184(4143): 1268.

DOI: https://doi.org/10.1126/science.184.4143 .1268 .

Chen J, Er HM, Mohamed SM, Chen YS. 2015. In vitro anti-inflammatory activity of fractionated Euphorbia hirta aqueous extract on rabbit synovial fibroblasts. Biomed. J., 38(4): 301-306. DOI: https://doi.org/10.4103/23194170.151031

Costea T, Nagy P, Ganea C, Szöllösi J, Mocanu MM. 2019. Molecular Mechanisms and Bioavailability of Polyphenols in Prostate Cancer. Int. J. Mol. Sci., 20(5). DOI: https://doi.org/10.3390/ijms20051062

De Guzman GQ, Dacanay ATL, Andaya BA, Alejandro GJD. 2016. Ethnopharmacological studies on the uses of Euphorbia hirta in the treatment of dengue in selected indigenous communities in Pangasinan (Philippines). J. Intercult. Ethnopharmacol., 5(3): 239243.

DOI: https://doi.org/10.5455/jice.2016033012 4637

Dikshit P, Tyagi MK, Shukla K, Gambhir JK, $\begin{array}{lll}\text { Shukla R. } & 2016 .\end{array}$ Antihypercholesterolemic and antioxidant effect of sterol rich methanol extract of stem of Musa sapientum (banana) in cholesterol fed wistar rats. $J$. Food Sci. Technol., 53(3): 1690-1697. DOI: https://doi.org/10.1007/s13197015-2096-5

Gill BS, Kumar S, Navgeet null. 2016. Triterpenes in cancer: significance and their influence. Mol. Biol. Rep., 43(9): 
881-896.

DOI:

https://doi.org/10.1007/s11033-016-

4032-9

Horoszewicz JS, Leong SS, Kawinski E, Karr JP, Rosenthal H, Chu TM, Mirand EA, Murphy GP. 1983. LNCaP model of human prostatic carcinoma. Cancer Res., 43(4): 1809-1818. DOI: https://cancerres.aacrjournals.org/content /43/4/1809.long

Iqbal J, Abbasi BA, Mahmood T, Kanwal S, Ali B, Shah SA, Khalil AT. 2017. Plantderived anticancer agents: A green anticancer approach. Asian Pac. J. Trop. Biomed., 7(12): 1129-1150. DOI: https://doi.org/10.1016/j.apjtb.2017.10.0 16

Ismail A, Mohamed M, Kwei YF, Yin KB. 2019. Euphorbia hirta methanolic extract displays potential antioxidant activity for the development of local natural products. Pharmacogn Res., 11(1): 78. DOI: https://doi.org/10.4103/pr.pr_113_18

Jain SC, Jain R, Sharma RA, Capasso F. 1997. Pharmacological investigation of Cassia italica. J. Ethnopharmacol., 58(2): 135142. DOI: https://doi.org/10.1016/s03788741(97)00091-3

Kwan YP, Saito T, Ibrahim D, Al-Hassan FMS, Ein Oon C, Chen Y, Jothy SL, Kanwar JR, Sasidharan S. 2016. Evaluation of the cytotoxicity, cell-cycle arrest, and apoptotic induction by Euphorbia hirta in MCF-7 breast cancer cells. Pharm. Biol., 54(7): 1223-1236. DOI:

https://doi.org/10.3109/13880209.2015.1 064451

Leesombun A, Boonmasawai S, Nishikawa Y. 2019. Ethanol extracts from Thai plants have anti-plasmodium and antitoxoplasma activities in vitro. Acta Parasitol., 64(2): 257-261. DOI: https://doi.org/10.2478/s11686-01900036-w
Miyata Y, Shida Y, Hakariya T, Sakai H. 2019. Anti-Cancer Effects of Green Tea Polyphenols Against Prostate Cancer. Molecules (Basel, Switzerland), 24(1). DOI:

https://doi.org/10.3390/molecules240101 93

Moore J, Yousef M, Tsiani E. 2016. Anticancer Effects of Rosemary (Rosmarinus officinalis L.) Extract and Rosemary Extract Polyphenols. Nutrients, 8(11). DOI: https://doi.org/10.3390/nu8110731

Nacoulma OG. 1996. Plantes médicales et pratiques médicinales traditionnelles au Burkina Faso. cas du plateau central. TomeI et II. Thèse doct., Univ. Ouaga., Ouagadougou. p. 242-285.

Nsereko G, Emudong P, Omujal J, Acai J, Kungu JM, Kabi F, Mugerwa S, Bugeza J. 2019. Comparison of the efficacy of crude methanolic extracts of Cassia occidentalis and Euphorbia hirta with levamisole-HCL against gastrointestinal nematodes of economic importance to goat production in Uganda. Trop. Anim. Health Prod., 51(8):2269-2278. DOI: https://doi.org/10.1007/s11250-01901939-6

Obi RK, Iroagba II, Ojiako OA. 2006. Virucidal potential of some edible Nigerian vegetables. Afr. J. Biotechnol., 5(19).

DOI: https://www.ajol.info/index.php/ajb/artic le/view/55854

Ouattara A, Traore Y, Ouattara GA, Konate G, Ouattara K, Coulibaly A. 2020. Antioxidant and anti-gastroenteritis activities of Funtumia elastica (Apocynaceae) and Caesalpinia bonduc (Caeasalpiniaceae). Int. J. Biol. Chem. Sci., 14(1): 170-180. DOI: https://www.ajol.info/index.php/ijbcs/art icle/view/194143

Perumal S, Mahmud R, Ismail S. 2017. Mechanism of Action of Isolated Caffeic Acid and Epicatechin 3-gallate from 
Euphorbia hirta against Pseudomonas aeruginosa. Pharmacogn. Mag., 13(2): S311-S315.

DOI:

https://doi.org/10.4103/pm.pm_309_15

Phuaklee P, Ruangnoo S, Itharat A. 2012. Antiinflammatory and antioxidant activities of extracts from Musa sapientum peel. J Med Assoc Thail Chotmaihet Thangphaet, 95 (1): S142-146.

Re R, Pellegrini N, Proteggente A, Pannala A, Yang M, Rice-Evans C. 1999. Antioxidant activity applying an improved ABTS radical cation decolorization assay. Free Radic. Biol. Med., 26(9-10): 1231-1237. DOI: 10.1016/s0891-5849(98)00315-3.

Reddy AJ, Dubey AK, Handu SS, Sharma P, Mediratta PK, Ahmed QM, Jain S. 2018. Anticonvulsant and Antioxidant Effects of Musa sapientum Stem Extract on Acute and Chronic Experimental Models of Epilepsy. Pharmacogn. Res., 10(1): 49-54.

DOI:

https://doi.org/10.4103/pr.pr_31_17

Reddy AJ, Handu SS, Dubey AK, Mediratta

PK, Shukla R, Ahmed QM. 2016. Effect of Musa sapientum Stem Extract on Animal Models of Depression. Pharmacogn. Res., 8(4): 249-252. DOI: https://doi.org/10.4103/09748490.188876

Salako OA, Akindele AJ, Balogun AO, Adeyemi OO. 2019. Investigation of Antidepressant, Anxiolytic and Sedative Activities of the Aqueous Leaf Extract of Musa sapientum Linn. (Banana; Musaceae). Drug Res., 69(3): 136-143. DOI: https://doi.org/10.1055/a-06517978

Sarr SO, Fall AD, Gueye R, Diop A, Sene B, Diatta K, Ndiaye B, Diop YM. 2015. Evaluation de l'activité antioxydante des extraits des feuilles de Aphania senegalensis (Sapindaceae) et de Saba senegalensis (Apocynaceae). Int. J. Biol.
Chem. Sci., 9(6): 2676-2684. DOI: https://doi.org/10.4314/ijbcs.v9i6.13

Sheikhlar A, Meng GY, Alimon R, Romano N, Ebrahimi M. 2017. Dietary Euphorbia hirta Extract Improved the Resistance of Sharptooth Catfish Clarias gariepinus to Aeromonas hydrophila. J. Aquat. Anim. Health, 29(4): 225-235. DOI: https://doi.org/10.1080/08997659.2017.1 374310

Shewamene Z, Dune T, Smith CA. 2020. Use of traditional and complementary medicine for maternal health and wellbeing by African migrant women in Australia: a mixed method study. BMC Complement. Med. Ther., 20(1): 60. DOI: https://doi.org/10.1186/s12906-0202852-6

Sitthiya K, Devkota L, Sadiq MB, Anal AK. 2018. Extraction and characterization of proteins from banana (Musa Sapientum L) flower and evaluation of antimicrobial activities. J. Food Sci. Technol., 55(2): 658-666.

DOI: https://doi.org/10.1007/s13197-0172975-z

Thirumalaisamy R, Ammashi S, Muthusamy G. 2018. Screening of anti-inflammatory phytocompounds from Crateva adansonii leaf extracts and its validation by in silico modeling. J. Genet. Eng. Biotechnol., 16(2): 711-719. DOI: https://doi.org/10.1016/j.jgeb.2018.03.00 4

Toyin YM, Khadijat OF, Saoban SS, Olakunle AT, Abraham BF, Luqman QA. 2012. Antidiarrheal activity of aqueous leaf extract of Ceratotheca sesamoides in rats. Bangladesh J. Pharmacol., 7(1): 14-20. DOI: https://doi.org/10.3329/bjp.v7i1.9789

Udeh NE, Onoja SO. 2015. Analgesic and free radical scavenging activities of hydromethanolic extract of Crateva adansonii stem bark. J. Intercult. Ethnopharmacol., 4(3): 224-227. DOI: 
https://doi.org/10.5455/jice.2015040305 5054

Velázquez E, Tournier HA, Mordujovich de Buschiazzo P, Saavedra G, Schinella GR. 2003. Antioxidant activity of Paraguayan plant extracts. Fitoterapia, 74(1): 91-97. DOI: $\quad$ https://doi.org/10.1016/S0367326X(02)00293-9

Xia M, Liu L, Qiu R, Li M, Huang W, Ren G, Zhang J. 2018. Anti-inflammatory and anxiolytic activities of Euphorbia hirta extract in neonatal asthmatic rats. $A M B$ Express, $\quad$ 8(1): $\quad$ 179. DOI: https://doi.org/10.1186/s13568-0180707-z

Yang ZN, Su BJ, Wang YQ, Liao HB, Chen ZF, Liang D. 2020. Isolation, Absolute Configuration, and Biological Activities of Chebulic Acid and Brevifolincarboxylic Acid Derivatives from Euphorbia hirta. J. Nat. Prod., 83(4): $\quad$ 985-995. DOI: https://doi.org/10.1021/acs.jnatprod.9b00 877

Yvette Fofie NB, Sanogo R, Coulibaly K, Kone-Bamba D. 2015. Minerals salt composition and secondary metabolites of Euphorbia hirta Linn., an antihyperglycemic plant. Pharmacogn. Res., 7(1): 7-13. DOI: https://doi.org/10.4103/09748490.147131

Zank S, Hanazaki N. 2017. The coexistence of traditional medicine and biomedicine: A study with local health experts in two Brazilian regions. Plos One, 12(4): e0174731.

DOI: https://doi.org/10.1371/journal.pone.017 4731

Zingue S, Cisilotto J, Tueche AB, Bishayee A, Mefegue FA, Sandjo LP, Magne Nde CB, Winter E, Michel T, Ndinteh DT, Awounfack CF, Silihe KK, Melachio Tanekou TT, Creczynski-Pasa TB, Njamen D. 2016. Crateva adansonii DC, an African ethnomedicinal plant, exerts cytotoxicity in vitro and prevents experimental mammary tumorigenesis in vivo. J. Ethnopharmacol., 190: 183-199. DOI:

https://doi.org/10.1016/j.jep.2016.06.004 